\author{
Monika Zalewska*
}

\title{
RÓŻNE WYMIARY ODPOWIEDZIALNOŚCI PRAWNEJ
}

\begin{abstract}
Streszczenie. Odpowiedzialność prawna jest złożonym zagadnieniem, wartym przeanalizowania zarówno na poziomie teoretycznym, jak i w odniesieniu do konkretnych przypadków praktycznych. Celem niniejszego artykułu jest analiza jednego z ujęć odpowiedzialności prawnej, które zaproponował Hans Kelsen. Zostanie zatem opisana konstrukcja zarachowania, a następnie pokazany mechanizm przełożenia zasady zarachowania na odpowiedzialność prawną. Wnioski bazują na stwierdzeniu niekompletności „czystej teorii prawa” w zakresie stosowania prawa.
\end{abstract}

Słowa kluczowe: odpowiedzialność prawna, zarachowanie, Hans Kelsen.

Odpowiedzialność prawna zalicza się do podstawowych zagadnień w zakresie nauki prawa. Ciekawą i oryginalną koncepcję odpowiedzialności zarysował Hans Kelsen, przedstawiając konstrukcję zarachowania. Jest to koncepcja ogólna, uniwersalna dla każdej gałęzi prawa, zatem potencjalnie mogąca pomóc w wyjaśnieniu pewnych zawiłości terminologicznych. W tym celu, w pierwszej części wyjaśniona zostanie sama konstrukcja zarachowania, by w części drugiej wskazać jej powiązania $\mathrm{z}$ odpowiedzialnością, a następnie pokazać jej działanie na wybranych przykładach.

\section{ZARACHOWANIE PERYFERYJNE}

Hans Kelsen wyróżniał dwa rodzaje zarachowania. Wpierw wprowadził do swoich rozważań zarachowanie centralne objaśniające powiązania proceduralne. Później znaczenie tej konstrukcji zostało zmarginalizowane przez przejęcie od Adolfa Merkla koncepcji dynamicznej struktury prawa opierającej się na powiazaniach formalnych i zasadzie delegacji. Rozważania na temat zarachowania centralnego zostaną tu odłożone na bok, ze względu na jego dość luźne związki z kwestią odpowiedzialności prawnej. $Z$ tego punktu widzenia znacznie bardziej interesujące jest zarachowanie peryferyjne. Kelsen wprowadził to rozwiązanie w czasie, gdy był pod silnym wpływem neokantyzmu. Zarachowanie peryferyjne odgrywa w normach prawnych podobną rolę do roli przyczynowości w wypowiedziach o bycie. O ile w tych drugich struktura zdania wygląda: „Jeśli A, to B”, to

* Uniwersytet Łódzki, Wydział Prawa i Administracji, Katedra Teorii i Filozofii Prawa, mzalewska@wpia.uni.lodz.pl 
W normach prawnych schemat przedstawia się następująco: „Jeśli A, to powinno B” (Kelsen 1934, 34). Słowo ,powinno” wskazuje właśnie na to szczególne powiązanie normatywne analogiczne do przyczynowości, czyli zarachowanie, które pełni dwojaką funkcję. Na poziomie nauki prawa umożliwia poznanie norm, a na poziomie samego prawa umożliwia przypisanie odpowiedzialności prawnej. Ta druga funkcja zostanie omówiona w następnej części, natomiast w tym miejscu warto wyjaśnić, w jaki sposób Kelsen powiązał konstrukcję zarachowania peryferyjnego z poznaniem. Jak już wcześniej zostało wspomniane, Kelsen był pod wpływem Kanta, a szczególnie jego teorii poznania. Według Kanta poznajemy zjawiska, natomiast rzecz sama w sobie pozostaje przed nami ukryta. W poznaniu zjawisk pomagają kategorie, które porządkują alogiczny empiryczny materiał. Jedną z podstawowych kategorii, obok kategorii substancji, jest u Kanta kategoria przyczynowości. Kelsen przeniósł te rozważania na grunt prawa. Zarachowanie jest dla niego kategorią analogiczną wobec kategorii przyczynowości. Tak jak ona pozwala uporządkować alogiczny materiał prawny i rozpoznać w nim normy. O ile Kant pytał o warunki możliwości poznania, to Kelsen szukał odpowiedzi na pytanie, jak możliwe jest poznanie prawne. W jaki sposób można rozpoznać normy i znaleźć ich differencia specifica wobec innych norm, na przykład norm moralnych (Alexy 2002, 181-202). Doszedł do wniosku, że wszystkie normy wyróżnia to, że należą do sfery powinności, natomiast prawo spośród nich odróżnia się przez zarachowanie i normę podstawową. Dzieje się tak, ponieważ zarachowanie łączy dwa stany faktyczne. Pierwszy z nich jest warunkiem zastosowania przymusu (np. kradzież), zaś drugi nadaje kompetencję organowi, by ów przymus zastosował. Według Kelsena żaden inny rodzaj norm nie posiada tego typu powiązania, ze względu na zinstytucjonalizowanie procesu związanego z nałożeniem przymusu. Również w ten sposób konstrukcja zarachowania ściśle się wiąże z kwestiami odpowiedzialności prawnej.

\section{ZARACHOWANIE I ODPOWIEDZIALNOŚĆ PRAWNA}

Odpowiedzialność prawna u Kelsena jest ściśle związana ze wspomnianym zarachowaniem oraz konstrukcją norm sprzężonych. Ta druga koncepcja zakłada istnienie dwóch rodzajów norm. Normy pierwotnej i normy wtórnej. W przykładzie:

N1: Kto nabył samochód, powinien go zarejestrować

N2: Kto nie zarejestrował samochodu, podlega karze normą pierwotną jest norma sankcjonująca (N2), natomiast normą wtórną norma sankcjonowana (N1). Zarachowanie pojawia się, gdy N1 nie zostanie wypełniona i organ zostaje na mocy N2 wyposażony w kompetencję wymierzenia sankcji. Pomysł norm sprzężonych nie był oryginalną koncepcją Kelsena, natomiast nowatorskie było odwrócenie porządku i uczynienie normą pierwotną N2. Kelsen uważa ją za fundamentalną dla nauki prawa, ponieważ, w przeciwieństwie 
do N1, pozwala na odróżnienie prawa od innych porządków normatywnych (Zalewska 2015, 195).

Zatem aby zaistniała odpowiedzialność prawna, musi zostać naruszona norma N1 zawierająca określone obowiązki skierowane do adresatów prawa. Naruszenia obowiązków mogą być różnego rodzaju. Może być to na przykład naruszenie dobra dziecka, narażenie na niebezpieczeństwo, czy też naruszenie obowiązków przez funkcjonariusza. Interesującym przypadkiem jest naruszenie praw człowieka, ze względu na to, że podmiotem naruszającym i odpowiedzialnym, któremu się zarachowuje fakt naruszenia, jest państwo. Dla Kelsena nie stanowi to jednak problemu ze względu na to, że wyznaje on monizm państwa i prawa oraz monizm prawa państwowego i międzynarodowego (Kelsen 1967). Traktuje zatem wszelkie prawo jako jeden wielki porządek prawny. Jeśli N1 zostanie naruszona, wówczas zarachowanie umożliwia zastosowanie sankcji. Jest to moment subsumpcji.

Aby odpowiedzialność prawna doszła do skutku, ciąg normatywny zainicjowany przez zarachowanie musi mieć swoją kontynuację w przepisach proceduralnych, na przykład dotyczących stron postępowania, czy też doręczeń. Kelsen niewiele zajmuje się kwestią stosowania prawa. Raczej postrzega zarachowanie jako ostatni takt w łańcuchu dynamicznych powiązań między normami, całą procedurę sprowadzając do kompetencji dla organu, by zastosował sankcję (Kelsen 1934, 92). Być może można tu dostrzec niekompletność czystej teorii prawa, która zatrzymuje się tam, gdzie mamy do czynienia z prawem w książkach i nie porusza aspektu prawa w działaniu. Jednak należy zwrócić uwagę, że Kelsen, ograniczony swoimi metodologicznymi założeniami, nie może wyjść poza sferę powinności i nie ma jak opisać sytuacji stosowania prawa inaczej niż w kategoriach ostatniej kompetencji, którą jest zarachowanie.

\section{PODSUMOWANIE}

W niniejszym opracowaniu została poddana analizie konstrukcja zarachowania, wiążąca się z kwestią odpowiedzialności prawnej. W drugiej części pokazany został mechanizm odpowiedzialności prawnej i jego związki z zarachowaniem oraz przykłady ilustrujące cały proces inicjujący zarachowanie. Są to trzy kroki. Po pierwsze, musi nastąpić zdarzenie naruszające obowiązek wyrażony w normie sankcjonowanej (N1). Po drugie, należy wtedy dokonać subsumpcji, którą umożliwia zarachowanie. Po trzecie, aby urzeczywistnić sankcję, muszą zostać spełnione warunki proceduralne w procesie stosowania prawa. W związku z ostatnim krokiem zauważone zostało, że Kelsen nie ma możliwości opisania go w należyty sposób, co prowokuje pytanie o kompletność czystej teorii prawa. 


\section{BIBLIOGRAFIA}

Alexy, Robert. 2002. „Hans Kelsen's Begriff Des Relativen Apriori”. W Neukantianismus und Rechtphilosophie. Hrsg. Robert Alexy, Lukas Meyer, Stanley L. Paulson. Baden-Baden: Nomos Verlagsgesellschaft.

Kelsen, Hans. 1934. Reine Rechtslehre. Wien-Leipzig.

Kelsen, Hans. 1967. Pure Theory of Law. New Jersey: The Lawbook Exchange.

Zalewska, Monika. 2015. "Gunman Situation Vicious Circle and Pure Theory of Law". W Problems of Normativity, Rules and Rule-Following. Eds. Michał Araszkiewicz, Paweł Banaś, Tomasz Gizbert-Studnicki, Krzysztof Płeszka. Cham, Heidelberg, New York, Dordrecht, London: Springer.

\section{Monika Zalewska}

\section{Various dimensions of legal liability}

Abstract. The legal liability is the issue of vast complexity and hence worth to analyze both on theoretical and practical level. The main goal is to analyze of one of the understandings of legal responsibility, imputation, proposed by Hans Kelsen. Therefore, first the concept of imputation will be described. Secondly, the mechanism will be revealed, which transforms imputation into legal responsibility. The conclusion includes the notion of incompleteness of Pure Theory of Law in application of law field.

Keywords: legal liability, imputation, Hans Kelsen. 